\section{Gobierno y protesta. \\ Problemas conceptuales y diversidad empírica \\ en el análisis de la protesta piquetera}

Esteban Iglesias
Esteban Iglesias es Profesor de la Facultad de Ciencia

Politica y RRIIl de la Universidad Nacional de Rosario.

Dirección postal: Facultad de Ciencia Política y RRIII, UNR, Riobamba y Berutti, Rosario.

e-mail: tatiglesias@arnet.com.ar

\section{Resumen}

En las perspectivas de la acción colectiva que se consolidaron desde mediados de los sesenta y comienzos de los setenta, los términos "gobierno" e videntidad" estaban planteados en términos de tensión. Esto constituye un problema teórico a considerar en la Argentina de fines de siglo $X X$ ya que se forjaron una serie de identidades al calor de la protesta donde la petición y la referencia al gobierno constituía y constituye un punto central. Lo cierto es que los grupos y organizaciones denominados "piqueteros" han establecido un conjunto heterogéneo de relaciones con las distintas instancias de gobierno, observándose así relaciones de integración en instancias nacionales de gobierno, de participación en políticas promovidas por el ámbito municipal (pero de confrontación en el plano provincial y nacionall, y, por último, de confrontación total con los diferentes niveles gubernamentales. La experiencia piquetera en la ciudad de Rosario confirma este conjunto de relaciones entre gobierno y acción colectiva. A la luz del fenómeno piquetero, este artículo tiene como propósito observar el modo en que las perspectivas sobre la acción colectiva se han planteado el conjunto de relaciones entre la dimensión politica y la construcción de identidades.

\section{Summary}

In the perspectives of the collective action that were consolidated from middle of the sixties and beginning of the seventies, the concepts "government» and "identity" were raised in tension terms. This constitutes a theoretical problem to considering in the Argentina of ends of XXth century since a series of identities were forged to the heat of the protest where the request and the reference to the government constituted and constitutes a central point. The certain thing is that the groups and organizations named upiqueteros" have established an heterogeneous set of relations with different instances (authorities) of governmet being observed this way integration relationships in government's national instances lauthorities), of participation in policies promoted by the municipal area (but of confrontation in the provincial and national plane), and, finally, of total confrontation with the different governmental levels. The "piquetera" experience in Rosario's city confirms this set of relations between government and collective action. In the light of the "piquetero" phenomenon, this article has the intention to observe the way in which the perspectives on the collective action have stated the set of relations between the political dimension and the construction of identities. 